\title{
Road Connectivity and Proximity of Fringe of Raipur City, Chhattisgarh
}

\author{
Shyama Prasanna Mukherjee \\ Ph.D. Scholar, S.O.S in Geography, Pt. Ravishankar Shukla University, Raipur, Chhattisgarh, India
}

*Corresponding Author: Shyama Prasanna Mukherjee, Ph.D. Scholar, S.O.S in Geography, Pt. Ravishankar Shukla University, Raipur, Chhattisgarh, India

\begin{abstract}
Road transport is quicker, convenient and more flexible. It is adoptable to individual requirements. Door to door collection and delivery is possible only in case of the roadways. Roads are a necessary compliment to other transport systems like Railways, water ways and air ways. Railway stations, ports and airports receive passengers through feeder roads. The density, connectivity and road network infrastructure are supreme factors to influence the socio-economic development of an area. Good road network infrastructure enable saving in the vehicle operation and maintenance costs, faster journeys, quick movement of perishable goods, reduced fuel consumptions and safer travel. In the case of Raipur's Fringe, the extension of roads (NH, SH, district road, village road) has assisted developmental activities, helped to overcome the remoteness and isolation as well as socio-economic, cultural and political integration. The total length of roads in Raipur City including fringe area is $3501.44 \mathrm{~km}$. The length of roads accounts for $1091.79 \mathrm{~km}$ in the City and $2409.65 \mathrm{~km}$. in the fringe. In the fringe area, the average density of roads is about 2154.75 meters per square kilometers where road density differs from primary fringe to secondary fringe of Raipur City.
\end{abstract}

Keywords: Types of roads, Pattern of roads, Road density, Road connectivity, Traffic volume, Proximity analysis.

\section{INTRODUCTION}

Roads play a significant role in the development of a town, city, region and a country, as they affect accessibility and the relative attractiveness of all locations (Gairhe, 2013). The accessibility of major roads provides relative advantages, where commercial users enjoy the opportunities created by the investment for rural road construction. Thus increase in demand for transport services and a corresponding decrease in the vehicle operating cost will be related with the improvement of road conditions (Walle, 2007). Rural road is most essential to facilitate market entry of small holders from village to town (World Bank, 2006). Female employment and off-farm opportunities are significantly increased by road intervention (Lakshin and Yemtsov, 2005; Walle, 2007). Road accessibility has profound impact on property values; and, properties located at the point where two or more roads meet command greater value than those located at the nodal points (Omoogun, 2006). Road transport considered as the only link to connect the rural and under developed areas with developed areas (Khan and Dehre, 1998). Maintenance of roads is essential for better and faster services, and minimum transport costs and travel time. Transport plays a vital role for socio-economic development of a society. The achievement of economic growth and poverty reduction requires employment, health services, homes, education and other amenities (Bhatta, 2004) which are not possible without good and adequate road network. Households with poor road access experience great transportation and transaction costs. There is a difference between the purchase and sale prices for the rural households with poor road access as they spend higher prices for the products they buy while they get lower prices for the products they sell (Bhatta, 2004). Road network provides the arterial network to facilitate trade, transport, social integration and economic development. It is most essential for easy movement of goods and people. Roads open up a place and bring in all kinds of development (Onuigbo and Orisakwe, 2013). Good road infrastructure helps to raise productivity and reduce production cost. It also helps to better management of traffic, provide environmental benefits for all income groups (Peter et al., 2015). 
Fringe of Raipur city is linked by national highway (NH.53, NH.30, and NH.130), State Highway (SH.10), district road (Raipur-Dhamtari, Raipur- Balodabazar) and many regional roads (RaipurPalari, Raipur-Gariaband, Raipur-Patan, etc.). In the study area road density and connectivity is different from road side to remote villages. Road side villages have higher density and connectivity than remote villages. Road side villages also enjoy with better road network infrastructure and optimum traffic. The total length of roads in Raipur City including fringe area is about $3501.44 \mathrm{~km}$. The length of roads accounts for $1091.79 \mathrm{~km}$ in the City and $2409.65 \mathrm{~km}$. in the fringe area of the City. In the fringe area, the average density of roads is about 2154.75 meters per square kilometers and the moderate road density is found in the secondary fringe of Raipur City.

\section{LITERATURE REVIEW}

Balk (1957), argued that the accessibility is a sole factor in the development of fringe. Adrashannawar (1968) measured the transportation needs in Mysore State and calculated ranking coefficients of the surfaced roads for each district and suggested useful measures for future development. Raza and Aggarwal (1986) in the book 'Transport Geography of India' discussed various quantitative methodologies to assess transport efficiency. Gautam (1992) in the book, 'Transport Geography of India: A Study of Chambal Division M.P', cited that the economic development now depends mainly on how efficiently different areas are linked through transport. The efficient transportation system promoted healthy economic and socio political set up. Backwardness and poverty are associated with immobility. Bryan, et. al. (1997) evaluated the impact of a major road improvement programme on the economic development of North Wales. Behera (1998) analyzed the existing transport condition of backward block in Orissa and described about road density, accessibility of road and utilization of road in the study area. Jana (1998) evaluated the availability of bus services in market villages in rural areas of Dakshmin Dinajpur, West Bengal. Khan and Dehre (1998) examined road density, accessibility and structure of passenger flow in Sheonath Basin, Madhya Pradesh and stated some problems of road transport as structural problems, organizational problems, lack of co-ordination etc. They also evaluated capability and utilization level of roads in Sheonath Basin. Sengupta (2001) observed many types of problems related to road network as insufficient capacity, congested city sections, safety, unavailable wayside amenities, Hawbaker (2006) described road development, housing growth and landscape fragmentation in Northern Wisconsin and stated that road network between 1937 to 1999 caused significant changes in landscape pattern in Sample Township (17) across three eco- regions in the study area. In this study, they also evaluated the road development history of Wisconsin. Awel (2007) evaluated the network modeling in vector and raster GIS and observed road length, road category, total road area, percentage of sub arterial road, percentage of local road etc. Lombard and Coetzer (2007) concluded that roads are primary mode of transportation for both passengers and freight in Africa. Obafemi et al. (2011) examined road density and connectivity level of Trans Amadi by GIS techniques. Beta Index was calculated to evaluate connectivity level. They also evaluated that road network of the study area is in good condition and connectivity level is high. Ilayaraja (2013) used Quantum GIS to identify shortest path between any two points within the road network in Neyveli Township, Cuddalore District. Nagne et al. (2013) analyzed transportation network of Aurangabad City by using Geographic Information System and calculated zone wise road density, population density, alpha index, beta index, gama index and eta index of Aurangabad Municipal Corporation. Manyazewal et al. (2014) used different techniques (road density, alpha index, gama Index, beta index etc.) to analyze the structure of road network of Hasanparthy town located in Warangal district, Telangana, India and concluded that the developed Advanced Rural Road Information System (ARRIS) will be useful to policy makers, government departments, Non-Government Organizations, general public for planning, development and management of road facilities in the rural areas. Sovik (2014) proposed GIS method for spatial network analysis and used density, angles, and the shape of polygon areas within a GIS network for pattern identification and analysis. Ford et al. (2015) analyzed Transport Accessibility Analysis Using GIS and Assessing Sustainable Transport in London and discussed Infrastructure improvements implemented in Baseline. Patil et al. (2015) analyzed the transport network of Nanded Taluka by using geographic information system and observed that the Nanded is good in transportation facilities. They also observed the road, road type, bus stops support infrastructure and land use, administrative boundaries etc. by using GIS software. Sidhtharthan and Durgadevagi (2015) analyzed the road 
network of Pondicherry Union Territory using GIS. This study emphasized on the length, type, location, connectivity of roads, and also addressed complex road network problem, ensuring better connectivity, shortest and quickest route etc.

\section{Material AND Methods}

The satellite imagery of the study area has been obtained from Google Earth, 2011(satellite image) to update the existing road network. Capture of information, layering, analysis and presentation of geographically referenced data. Digitized the roads through Arcgis. The Fringe of Raipur city consists of 130 villages. Out of 130 villages $10 \%$ villages were selected for the survey which has been accepted at $95 \%$ confidence level or 0.05 significant levels. The selection of sample villages is an important factor to determine the exactness of the results so a great care has been taken to the selection of sample villages. Out of 13 villages $(10 \%), 6$ villages have been selected from road side and other 7 villages have been selected from remote areas through purposive sampling.

\section{RESUlT AND DISCUSSION}

\subsection{Growth of Roads}

After independence, road transport has emerged as one of the dominant factors to transfer goods and services. In the year 1951, the length of roads in India was $4,00000 \mathrm{Km}$. and after the 4 decades in 1991 it had increased to $19,98,200 \mathrm{Km}$ (Economic survey, 2009-10). In the present time the total length of road in India is about 48, 65,394 Km. (MSPI, 2014).

Road network facilitates the movement of passenger and freight across the country. It is the most vital for inclusive economic growth by minimizing total transportation cost in terms of production, distribution and consumption. The road pattern of a region is an image of the contemporary During Maratha period, the temporary and permanent basis for the road network was led away in Raipur division during the Maratha rule. In this period effort was made to construct Great Eastern Road (now known as NH.53) from Nagpur to Sambalpur.

In the year 1818, the construction of Great Eastern Road was completed. During this period the Great Eastern Road was extended from Nagpur to Raipur. In the year 1817, this road was extended up to Sambalur. This road was most vital for the movement of passenger and freight across the fringe of Raipur City. In the year 1860 Raipur-Bilaspur road was constructed (now known as NH.130), which was another important metalled road in the study area.

In present time Raipur city and its fringe is connected by National Highway no.53 with $38 \mathrm{~km}$. length in the study area National Highway No.30 with $29 \mathrm{~km}$. length within fringe boundary and National Highway No. 130 with the length of about $26 \mathrm{~km}$. pass through the fringe area. The fringe area is also connected by State Highway and district roads viz. Raipur-Balodabazar Road, Raipur-Sarguja Road etc.

Now, many regional roads are developed in Raipur city and its fringe area viz. Raipur to Arang , Raipur to Simga, Raipur to Tilda, Raipur to Mana (15 km.), Raipur to Patan (19km.), Raipur to Mujaghan (8km.), Raipur to Sejbahar (12 km.) etc.

\subsection{Types of Road}

On the first road development plan (Nagpur Plan) of 1943, roads were classified on the basis of their status and constructional materials. On the basis of constructional materials roads may be classified as -i) cement - concrete, ii) painted, iii) metalled and iv) fair- weather road.

After Independence, the First Five Years Plan (1951-56) classified road into national highways, state highways, district roads and village roads. Indian Road Congress adopted the road development plan (1981-2001), which proposed new road classification system as: i) primary system, consisting of expressways and national highways, ii) secondary system, consisting of state highways and major district roads iii) tertiary system consisting of other district roads and village roads.

The road network of the fringe of Raipur City consists of a variety of roads like metalled roads, unmetalled roads, cement-concrete roads etc. The total length of roads in Raipur City including fringe area is about $3501.44 \mathrm{~km}$. The length of roads accounts for $1091.79 \mathrm{~km}$ in the City and $2409.65 \mathrm{~km}$. in the fringe area of the City. 


\subsection{National Highways}

National Highways are the arterial roads of the country for inter-state and strategic defense movements and are the primary long-distance roadways. There are 228 National Highways in India which traverse a distance of about $76818 \mathrm{~km}$. (Basic Road Statistics of India, 2011-12). The total length of National Highways in the fringe of Raipur City is about $93 \mathrm{~km}$. and the length of National Highway in the City is about only $37 \mathrm{~km}$. (Table:1). The study area has three major National Highways i.e. NH.6 (NH.53), NH.43 (NH.30) and NH.200 (NH.130). The NH.53 has significant impact to transfer goods and people from City to Fringe and Fringe to City, which traverses a distance about $38 \mathrm{~km}$. from north west to south east in the study area. The NH.53 (Mumbai-Kolkata Road) spread over Jora, Mandir Hasaud, Nawagaon, Umaria and Rewa villages. These villages are directly connected with City through this highway. The National Highway 130 also known as RaipurBilaspur-Chandikhol Road traverses a distance of about $26 \mathrm{~km}$. from north to south in the study area connecting Rawabhata, Dhaneli, Siltara and Dharsiwa villages. It has great impact on industrial development in the study area. The National Highway no.30 extends from Raipur to Vizianagaram. In the study area, this road covers a distance of about $29 \mathrm{~km}$. and spans the area from north to south via Deopuri, Banarsi, Mana, Upperwara and Kurru village (Fig.1).

Table1. National Highways in the Study Area

\begin{tabular}{|c|c|c|c|c|}
\hline $\begin{array}{c}\text { National } \\
\text { Highway }\end{array}$ & $\begin{array}{c}\text { Length in } \\
\text { India } \\
(\mathrm{Km} .)\end{array}$ & $\begin{array}{c}\text { Length in } \\
\text { Chhattisgarh } \\
(\mathrm{Km} .)\end{array}$ & $\begin{array}{c}\text { Length in } \\
\text { Study } \\
\text { Area(Km. })\end{array}$ \\
\hline NH.53 & $\begin{array}{c}\text { Hajira-Dhule-Nagpur-Raipur- } \\
\text { Sambalpur-Baharagora-Calcutta }\end{array}$ & 1949 & 314 & 38 \\
\hline NH.130 & $\begin{array}{c}\text { Raipur-Bilaspur-Raigarh-Kanaktora- } \\
\text { Jharsuguda-KochindaDeogarh- } \\
\text { Talcher-Chandhikhol }\end{array}$ & 740 & 300 & 26 \\
\hline NH.30 & $\begin{array}{c}\text { Raipur-Vizianagaram Junction with } \\
\text { National Highway No. 5 near } \\
\text { Natavalasa }\end{array}$ & 551 & 316 & 29 \\
\hline
\end{tabular}

Source: www.nhai.org./doc/2012 and Personal survey 2010-11.

\subsection{State Highway}

State Highways are arterial roads in a state for inter district movement which connect the state capital, district headquarters and important towns and link up with the National Highways.

The study area has only one State Highway (SH.10), which extends from Raipur to Balodabazar with $96 \mathrm{~km}$ length from west to east. In the study area this road passes through Amaseoni, Semaria, Nardaha, Dondekhurd and Dondekalan villages. This road covers a distance of about $19 \mathrm{~km}$. in the study area. This road links-up with the Great Eastern Road (G.E. Road) in city centre (Raipur City). It has great role in serving goods and people to and fro Raipur to Balodabazar.

\subsection{Major Districts Roads}

Major District Roads are arterial roads within a district connecting areas of production with markets and connecting these with each other or with the State Highways and National Highways. It also connects rural areas to District headquarters within the state.

The Study area has some major district roads i.e. Raipur-Dhamtari Road, Raipur-Bhatgaon Road, Raipur-Arang Road, Raipur- Simga Road, Raipur-Tilda Road, Raipur-Avanpur Road etc.

\subsection{Village Roads}

Village roads serve as the feeder roads of the other highways as well as the roads for inter village movements which pass through the rural areas connecting the villages to one another and to the nearest District Roads, State Highways and National Highways.

The fringe of Raipur City has several village roads. These roads connect the villages to one another. In the study area, the important village roads are Raipur-Kandul, Raipur-Sejbahar, Kandul-Sejbahar, Amaseoni-Tulsi, Siltara-Nagargaon, Siltara- Kanhera, Darba-Mandir Hasaud, Dhansuli-Dondekhurd, Mana-Barouda etc. 


\subsection{Patterns of Road}

Raipur is well connected by roads with Nagpur, Jabalpur, Bilaspur and Jagdalpur. It is also connected with all the district headquarters by all Weather roads. The NH.53, NH.30 and NH.130 spread over the city and its fringe area, where NH.53 extends from west to east in the study area. National Highway 53 connects Bhilai, Durg and Rajnandgaon cities. NH-30 originates at Raipur and passes through Dhamtari, Jagdalpur and NH-130 extend from Raipur to Bilaspur. The city and its fringe are connected by major roads to the urban centers viz. Balodabazar, Dhamtari, Bilaspur etc. The study area has a fairly satisfactory all weather road linkage with all-important urban centers. Various patterns of road network has been found in the City and its fringe area viz. grid pattern, radial pattern, rectangular pattern, linear pattern, hexagonal pattern etc. (Fig.1)

\subsection{Grid Pattern}

The Grid pattern of road network has developed over a small area of the northern portion of fringe. This pattern is located on Urkura, Rawabhata, Birgaon, Urla and Sarora village. Another Grid pattern road network has been found on southern portion of the fringe area, just beyond the city boundary and spread over Deopuri, Dumurtarai and Boriyakala village.

\subsection{Rectangular Pattern}

The rectangular pattern of road network has developed over a Naya Raipur in the southern portion of the fringe. This area is located between NH.53 and NH.30, spread over Jhanj, Kuhera, Nawagaon, Kayabandha, Kodrabhatha, Palaud, Parsada and Sendh village (Naya Raipur).

\subsection{Linear Pattern}

Linear pattern of road network is located in the north eastern part of the fringe of Raipur City. It is an unplanned road network pattern in the study area. It spreads over Tanda, Giraud, Tekari, Mandhar, Neurdih, Chhapora, Bhurkoni, Semariya and Barauda village. Many types of village roads and others roads are link-up in this pattern.

\subsection{Crude Pattern}

Crude pattern is generally found in the major part of the rural urban fringe of Raipur City. This pattern is most common in outer fringe area of Raipur City. This pattern spread over Banjari, Cheria, Kurru, Paunta, Nawagaon, Kharkhardih, Ganaud and Tandul villages in the south and Nardaha, Dhansuli, Sakri, Tulsi and Bahenakadi villages in the east portion of the fringe. This pattern is also seen in the north eastern part of the fringe area, spread over Parastaraj, Munrethi, Bahensar, Sondra, Kumhari and Kanhera villages. It is an indicator of unplanned road network pattern.

There are many tentacles grown from the main road, which is considered as local roads. Usually these local roads treat some times as the tentacles of the main roads and such tentacle pattern of road system is developed here and there through the fringe of Raipur city.

Various factors are responsible for the development of various pattern of road network in the fringe of Raipur City. In the study area, the regional patterns of road networks mostly depend on land use characteristics. Land farming, water feature, vegetation, soil all have their affect on the position of the road upon the land. Similarly cultural milieu, the position of the settlements, the system of land survey and the type of economic activity have equal effect upon the location of the road in any given area. Relief features stand out perhaps more prominent that any other controlling factors for road location.

\subsection{Road Density}

Road density is an index of economic enrichment and standards of living of any nation as it measures the degree of transportation service in that nation. It is used to measure the road network development. It is determined as the length of road per unit area. The road density of the study area is calculated by the equation of-

$$
\text { Road Density }=\text { Total Length of Road/ Total Area. }
$$

In the fringe area, the average density of roads is about 2154.75 meters per square kilometers. The road density is about 3630.24 meters per sq.km. in the City fringe and the City has higher density than the study area ,which is 9161.07 meters per sq. $\mathrm{km}$. 
On the basis of road density the City and its fringe have been divided into 4 major categories (Fig.2), i.e.

i) Very High Density Zone (above 6000 meters/sq km.)

ii) High Density Zone (4000 - 6000 meters/ sq. km.)

iii) Moderate Density Zone (2000 - 4000 meters/ sq. km.)

iv) Low Density Zone (below 2000 meters/ sq. km.).

The very high density zone is mainly spread over the City area and just beyond the outer limit of the City due to the development of commercial and industrial activities. In the study area, very high density is mainly found in Urla, Urkura, Birgaon, Bhurkoni, Amaseoni, Sankri, Pirda, Jora, Boriyakhurd, Deopuri, Dunda, Dumurtarai, Temri, Banarsi, Boriyakala villages. Due to Naya Raipur Development Project, very high density is also found in the south eastern portion of the fringe of Raipur City specially in Chicha and Kodra Bhatha village.

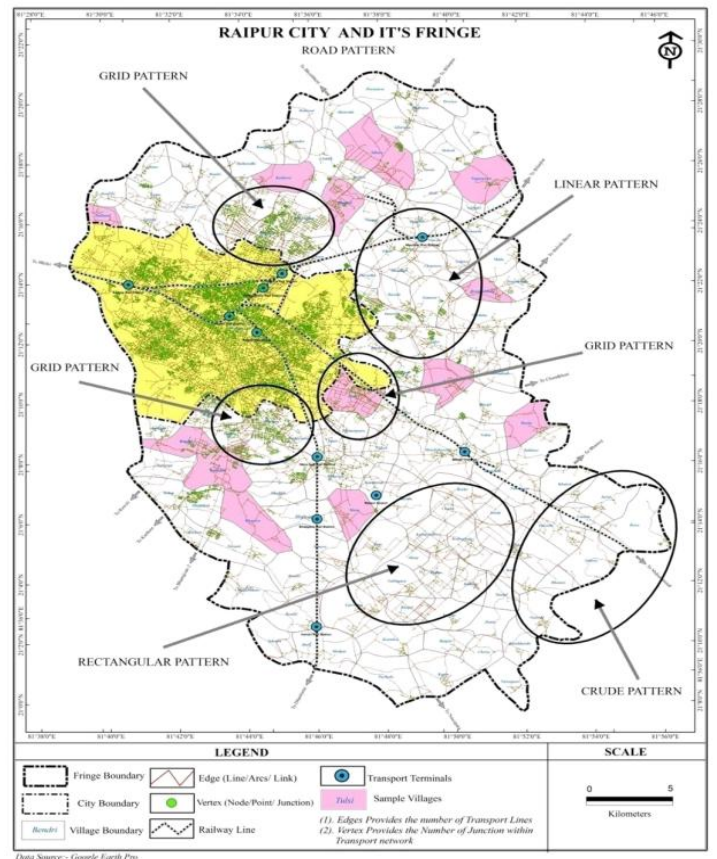

Fig1.

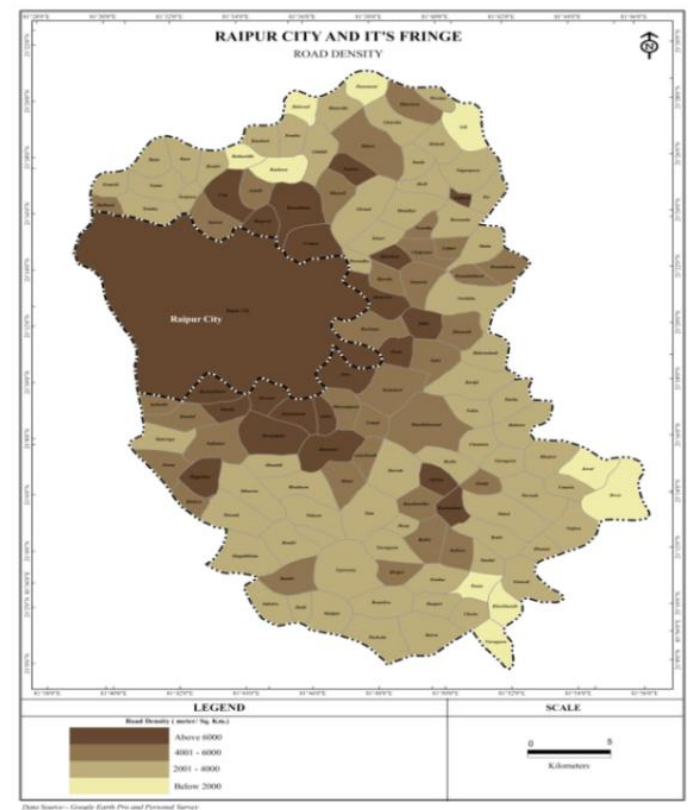

Figure2. 
High Density is found in the primary rural urban fringe of Raipur City. The primary fringe is well connected to the City through several roads. The village Kandul, Sejbahar, Doma, Mana, MandirHasaud, Serikhedi, Semariya, Chhapora, Siltara and Hatband are under high density zone. This zone is located at just outer limit of the very high density zone. This zone is highly concentrated with heavy and light industries.

The moderate type of road density is most common in the secondary fringe of Raipur City. But due to low connectivity, moderate road density is also found within inner fringe boundary, specially in Hatband, Kandul, Tendua, Parsulidih and Datrenga villages.

Low density zone is located in the outer limit of the secondary fringe area. It is usually found on extreme north and south portion of the fringe area. The village Parastaraj, Bahensar, Gordi, Kanhera, Patharidih, Jaraud, Reewa, Paunta, Kharkhardih and Nawagaon are under low density zone. Due to inadequate road network, the road density is less than $2 \mathrm{~km}$. per sq. $\mathrm{km}$. in this zone.

Table2. Road Density in Sample Villages

\begin{tabular}{|c|c|c|c|c|}
\hline $\begin{array}{l}\text { Village } \\
\text { Type }\end{array}$ & $\begin{array}{l}\text { Village } \\
\text { Name }\end{array}$ & $\begin{array}{l}\text { Area in } \\
\text { Sq. Km. }\end{array}$ & $\begin{array}{c}\text { Length of Roads } \\
\text { in Meters }\end{array}$ & $\begin{array}{l}\text { Road Density In } \\
\text { Meters/Sq.Km. }\end{array}$ \\
\hline \multirow{7}{*}{ 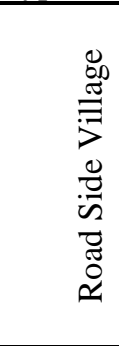 } & Dondekhurd & 3.26 & 10674.06 & 3274.25 \\
\hline & Sejbahar & 6.8 & 23377.24 & 3437.83 \\
\hline & Mana & 10.68 & 30565.63 & 2861.95 \\
\hline & Dhaneli & 4.88 & 14654.84 & 3003.04 \\
\hline & Jora & 3.96 & 16426.32 & 4148.06 \\
\hline & Siltara & 11.38 & 45309.01 & 3981.46 \\
\hline & Total & 40.96 & 141007.09 & 3442.56 \\
\hline \multirow{10}{*}{ 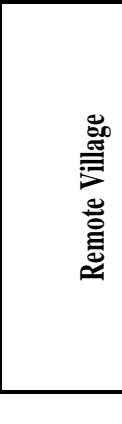 } & Dhusera & 7.53 & 9877.10 & 1311.70 \\
\hline & Kanhera & 2.81 & 4908.17 & 1746.68 \\
\hline & Nagargaon & 5.11 & 10237.73 & 2003.47 \\
\hline & Darba & 5.42 & 8536.66 & 1575.03 \\
\hline & Nagargaon & 5.11 & 10237.73 & 2003.47 \\
\hline & Tulsi & 7.44 & 12206.81 & 1640.70 \\
\hline & Hatband & 1.53 & 3234.21 & 2113.86 \\
\hline & Kandul & 4.53 & 10343.35 & 2283.30 \\
\hline & Total & 34.37 & 59344.03 & 1726.62 \\
\hline & Gr.TOTAL & 75.33 & 200351.12 & 2659.65 \\
\hline
\end{tabular}

Source: Personal Survey, 2010-11.

On an average, the density of road is 2659.65 meters/ sq.km. among the sample villages (Table 2). The density of roads is 3442.56 meters/ sq. $\mathrm{km}$. in road side villages, which is higher than the regional average. On the other hand, the density of road is 1726.62 meters/ sq. $\mathrm{km}$. in remote villages, which is lower than the regional average (2659.65 meters/ sq.km.).

The highest road density has been recorded in Jora village (4148.06 meters/sq.km.), followed by Siltara (3981.46 meters/sq.km.), Sejbahar (3437.83 meters/sq.km.), Dondekhurd (3274.25 meters/sq.km.), Dhaneli (3003.04 meters/sq.km.), Mana (2861.95 meters/sq.km.), Kandul (2283.30 meters/sq.km.), Hatband (2113.86 meters/sq.km.), Nagargaon (2003.47 meters/sq.km.), Tulsi (1948.70 meters/sq.km.), Kanhera (1746.68 meters/sq.km.), Dhusera (1711.70 meters/sq.km.) and Darba (1575.03 meters/sq.km.).

\subsection{Road Connectivity}

The arrangement of road network is generally abstracted as a direct planner graph $(\mathrm{G}=\mathrm{v}, \mathrm{e})$. Where, ' $v$ ' refers to numbers of nodes or vertex and 'e' refers to number of edges or lines.

The connectivity level of road network in the fringe of Raipur City has been measured by various connectivity indices through Alpha Index, Beta Index, Gamma Index and Eta index (Table 4.3). These indices are most vital to identify the growth within network structure and also for change detection system (Nagne et. al., 2013). In the Study area, the value of Alpha, Beta and Gamma Index are $0.1876,1.3751$ and 0.4585 respectively. The values of these indices are higher in the City area 
$(\alpha=0.2621, \beta=1.5242, \gamma=0.5082)$. The City with its fringe has 0.2103 Alpha Index, 1.4205 Beta Index and 0.4736 Gamma Index which are less than the City (Raipur City) but more than the Fringe Area (Fig.3).

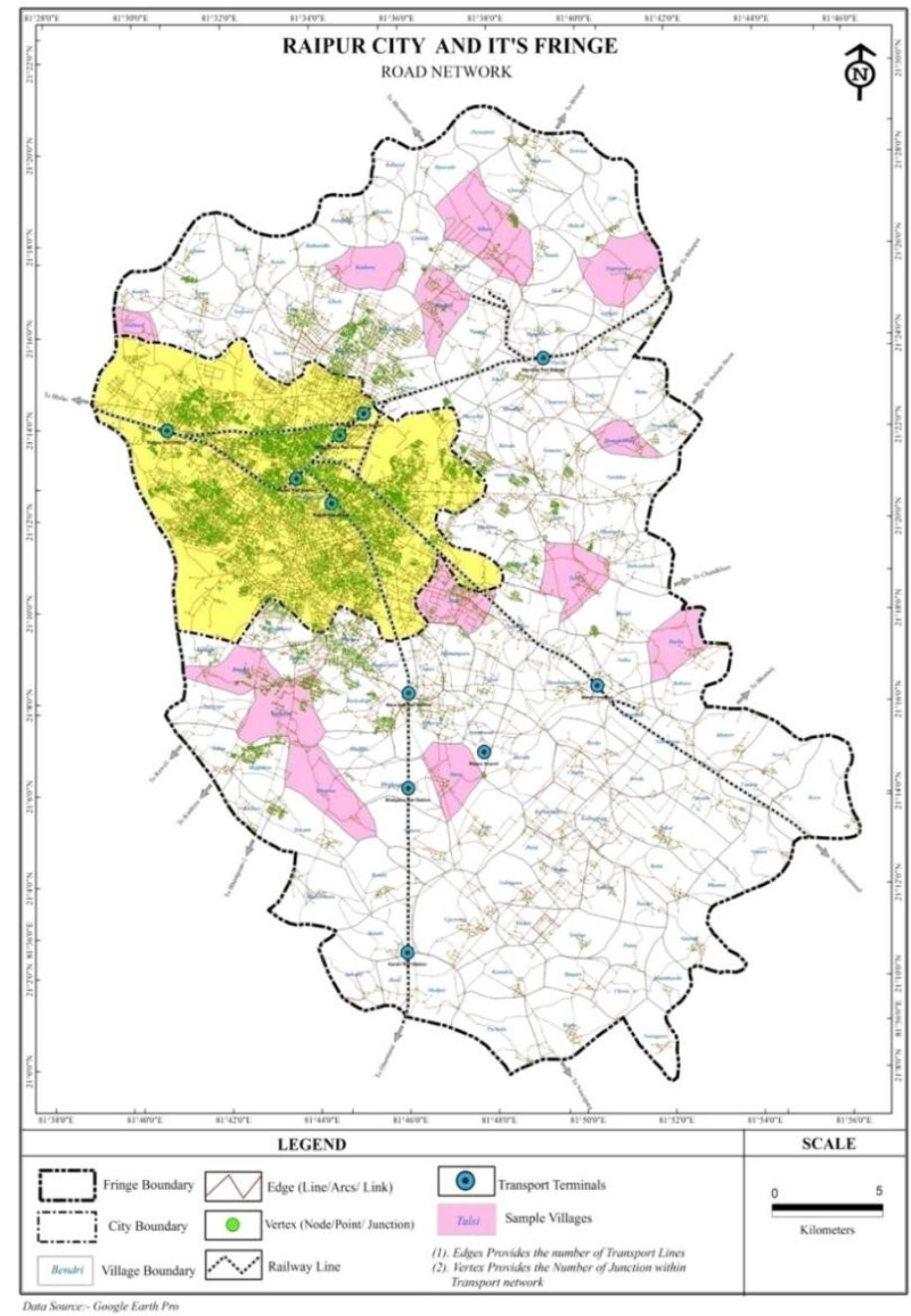

Figure3.

Table3.

\begin{tabular}{|c|c|c|c|c|c|c|c|c|}
\hline \multicolumn{9}{|c|}{ Road Connectivity } \\
\hline \multirow[b]{2}{*}{$\begin{array}{c}\text { Village } \\
\text { Type }\end{array}$} & \multirow[b]{2}{*}{ Village Name } & \multirow{2}{*}{$\begin{array}{c}\text { Length } \\
\text { Of } \\
\text { Roads } \\
(\mathrm{km} .)\end{array}$} & $\begin{array}{l}\text { (Point/ } \\
\text { Node) }\end{array}$ & $\begin{array}{l}\text { (Line/ } \\
\text { Arcs) }\end{array}$ & $\begin{array}{l}\text { Alpha } \\
\text { Index }\end{array}$ & $\begin{array}{l}\text { Beta } \\
\text { Index }\end{array}$ & $\begin{array}{c}\text { Gamma } \\
\text { Index }\end{array}$ & $\begin{array}{c}\text { Eta } \\
\text { Index }\end{array}$ \\
\hline & & & $\begin{array}{l}\text { Vertex } \\
\text { (v) }\end{array}$ & $\begin{array}{l}\text { edges } \\
\text { (e) }\end{array}$ & $a=(e-v+1) /(2 v-5)$ & $\beta=e / v$ & $\gamma=e /(3(v-2))$ & $\eta=\mathrm{I} / \mathrm{e}$ \\
\hline \multirow{7}{*}{ 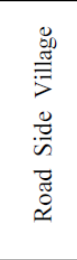 } & Dondekhurd & 10.67 & 31 & 46 & 0.2456 & 1.4839 & 0.5287 & 0.2320 \\
\hline & Sejbahar & 23.38 & 122 & 244 & 0.5063 & 2.0000 & 0.6778 & 0.0958 \\
\hline & Mana & 30.57 & 36 & 54 & 0.2537 & 1.5000 & 0.5294 & 0.5660 \\
\hline & Dhaneli & 14.65 & 118 & 163 & 0.1905 & 1.3814 & 0.4684 & 0.0899 \\
\hline & Jora & 16.43 & 203 & 286 & 0.2045 & 1.4089 & 0.4743 & 0.0574 \\
\hline & Siltara & 45.31 & 70 & 89 & 0.1333 & 1.2714 & 0.4363 & 0.5091 \\
\hline & Total & 141.01 & 580 & 882 & 0.2606 & 1.5207 & 0.5087 & 0.1599 \\
\hline \multirow{9}{*}{ 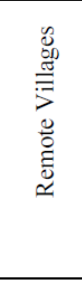 } & Dhusera & 9.88 & 16 & 21 & 0.1481 & 1.3125 & 0.5000 & 0.4703 \\
\hline & Kanhera & 4.91 & 10 & 14 & 0.2000 & 1.4000 & 0.5833 & 0.3506 \\
\hline & Darba & 8.54 & 9 & 11 & 0.0769 & 1.2222 & 0.5238 & 0.7761 \\
\hline & Nagargaon & 10.24 & 16 & 20 & 0.1111 & 1.2500 & 0.4762 & 0.5119 \\
\hline & Tulsi & 12.21 & 15 & 19 & 0.1200 & 1.2667 & 0.4872 & 0.6425 \\
\hline & Hathband & 3.23 & 9 & 11 & 0.0769 & 1.3333 & 0.5238 & 0.2940 \\
\hline & Kandul & 10.34 & 56 & 69 & 0.1121 & 1.2321 & 0.4259 & 0.1499 \\
\hline & Total & 59.34 & 131 & 165 & 0.1284 & 1.2595 & 0.4264 & 0.3597 \\
\hline & Gr. Total & 200.35 & 711 & 1047 & 0.2364 & 1.4726 & 0.4922 & 0.1914 \\
\hline
\end{tabular}




\subsection{Alpha Index}

Alpha index is the ratio between observed numbers of circuits and the number of maximum possible circuits in the network. The value of Alpha Index ranges from 0 to 1 , where the 0 value indicates no circuits and 1 value represents that the actual number of circuits is equal to the number of maximum possible circuits in the network or a complete interconnected network.

$\alpha=(\mathrm{e}-\mathrm{v}+1) /(2 \mathrm{v}-5)$ Where,

$\alpha=$ Alpha Index

$\mathrm{e}=$ Number of edges (Line) $\mathrm{v}=$ Number of Vertex (Node)

The Alpha index value of the selected villages is 0.2364 . Whereas road side sample villages are having 0.2606 alpha index and remote villages have lower value $(0.1284)$, because there are very less alternative routes to reach from one place (end) to another (Table 3).
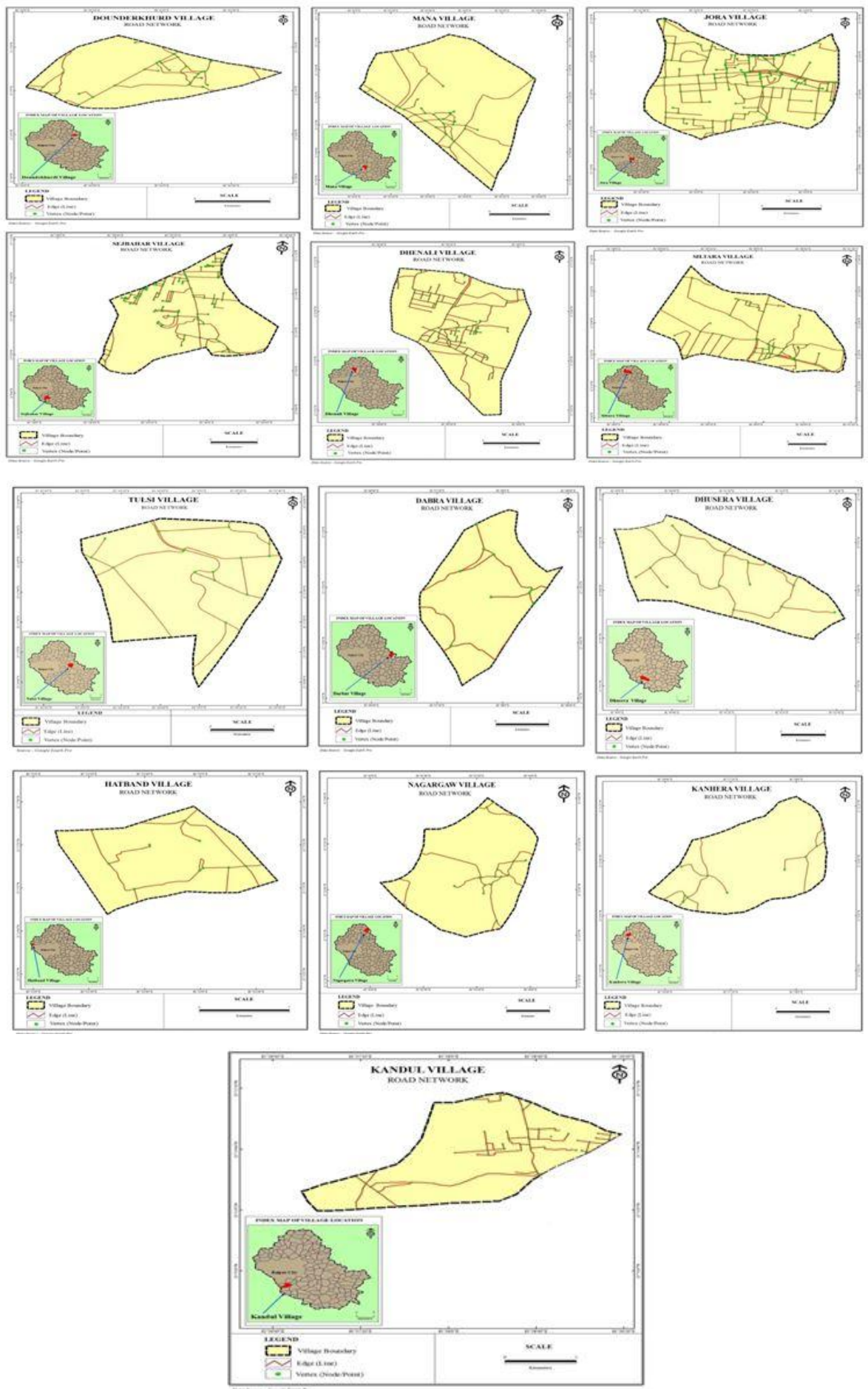

Figure4. 
The value of Alpha Index ranges from 0.0769 in Darba to 0.5063 in Sejbahar. There are only 3 villges viz. Dondekhurd, Sejbahar and Mana with 0.2456, 0.5063 and 0.2537 Alpha Index, with more than the regional average (0.2364). On the other hand, there are 10 villages viz. Dhaneli, Jora, Siltara, Dhusera, Kanhera, Darba, Nagargaon, Tulsi, Hatband and Kandul, where the value of Alpha Index is less than the regional average (0.2346). Thus it is clear that, except Dondekhurd, Sejbahar and Mana, all the selected sample villages have inadequate alternative routes to reach from one point to another point. The Village Sejbahar has relatively better interconnected network than other sample villages (Fig.4).

\title{
4.15. Beta Index
}

Beta Index of the connectivity has been developed by Kansky in the year 1963. Beta Index is a ratio of the number of edges to the number of nodes. It is more helpful to decide the connectivity level of the roads. It is a simple network analysis where no circuits are involved. The value of this index ranges from 0 to 3 , where 0 values indicate the network consists of nodes without any arc and 1 and greater value indicates the well connected network.

$\beta=\mathrm{e} / \mathrm{v}$

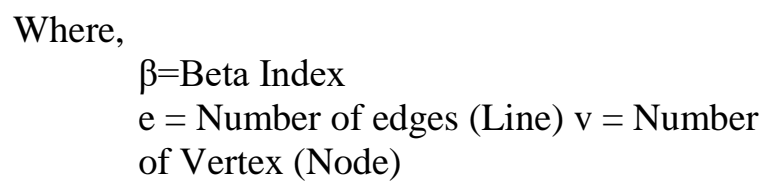

The value of Beta Index of the sample villages is about 1.4726. The value of this index differs from road side to remote villages. Road side villages have higher Beta value (1.5207) than the remote villages (1.2595) because networks are relatively well connected in road side villages (Table 4.13). These villages have also greater Beta index than the regional average (1.4726).

The value of Beta Index ranges from 1.2222 in Darba to 2.0000 in Sejbahar. In four villages viz. Darba, Nagargaon, Hatband and Kandul, the value of Beta Index is below the regional average (1.4726). While in other 9 villages, namely Dondekhurd, Sejbahar, Mana, Dhaneli, Jora, Siltara, Dhusera, Kanhera and Tulsi the value of Beta Index is more than the regional average (1.4726). The value of Beta index shows that the connectivity of road network is high in Sejbahar village and the connectivity is relatively poor in Darba village. The village Sejbahar (2.0000) and Mana (1.5000) belong have a better connectivity of road network than the other sample villages.

\subsection{Gamma Index}

Gama index is the ratio of the observed number of edges to the maximum possible number of edges in the network. It is a valuable measure of accessibility of individual nodes. The value of Gama Index ranges from 0 to 1 , where 0 value indicates no link between nodes and 1 value represents that every node in the road network has a link to every other node. The index is expressed by following equation:

$\gamma=\mathrm{e} /(3(\mathrm{v}-2))$

\author{
Where, $\gamma=$ Gama Index \\ $\mathrm{e}=$ Number of edges (Line) $\mathrm{v}=$ Number \\ of Vertex (Node)
}

The Gamma value of sample villages is 0.4264 which is more than the fringe $(0.1876)$ but less than the City (0.5082). The value of Gamma Index is about 0.5087 in road side village and 0.4264 in remote village. The road side villages have a higher value than the regional average (0.4264).

The highest value of Gamma Index has been recorded in Sejbahar (0.6778), followed by Kanhera (0.5833), Mana (0.5294), Dondekhud (0.5287), Darba, Hatband (0.5238), Dhusera (0.5000), Tulsi (0.4872), Nagargaon (0.4762), Jora (0.4743), Dhaneli (0.4684), Siltara (0.4363) and Kandul (0.4259). The value of Gamma index indicates that maximum number of connections with direct link to all nodes have been found in Sejbahar, Kanhera and Mana villages.

\subsection{Eta Index}

Eta Index measures the average edges length in the network. It is also used as a measure of speed in traffic network. The value of Eta Index ranges from 0 to 1 . Where 0 value indicates no network and 1 value indicates maximum average length of network. The quation of Eta Index is as follows: 


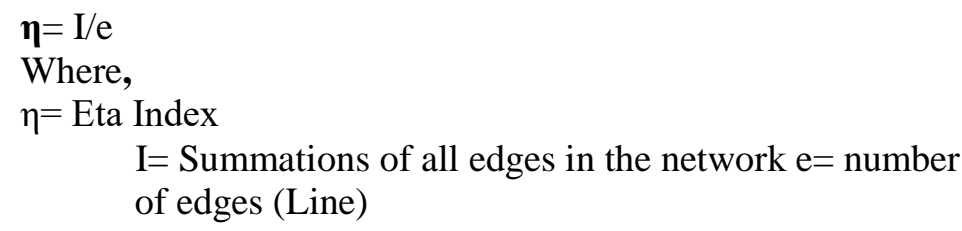

In the sample villages the value of Eta index is 0.1914 which is less than the fringe $(0.3471)$ but more than the City (0.1177). The value of Eta Index is 0.1599 in road side villages and 0.3597 in remote villages. Road side villages have lower value than the regional average $(0.1914)$ which indicates that the number of vertices is proportionately higher to length of roads.

The value of Eta Index ranges from 0.0574 in Jora to 0.7761 in Darba. There are only 4 villages viz. Sejbahar, Dhaneli, Jora and Kandul, where the value of Eta Index is less than the regional average (0.1914). As against this, there are 9 villages viz. Dondekhurd, Mana, Siltara, Dhusera, Kanhera, Darba, Nagargaon, Tulsi and Hatband, where the value of Eta index is more than the regional average. On the basis of Eta value it is clear that the average length of road is higher in comparison to junctions in the remote sample villages. On the other hand, due to the addition of new links, the average length of road has been decreased in road side villages.

\subsection{Traffic Volume}

Traffic volumes on roads are key indicator of motorized activity in any area. Traffic volume represents the total volume of vehicles (Up and Down) on a road at a particular time. Table 4 shows the Average Daily Traffic (ADT) in the study area recorded during seven days. Table 4 also reveals Passenger Car Unit (PCU) values, which are most essential to measure the rate of traffic flow in the study area.

Table4. Average Daily Traffic on Different Routes

\begin{tabular}{|c|c|c|c|c|c|c|c|c|c|c|c|c|}
\hline Types of Vehicles & 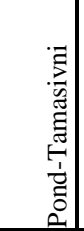 & 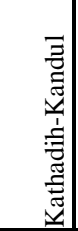 & 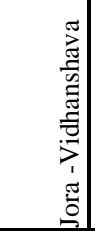 & 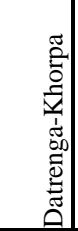 & 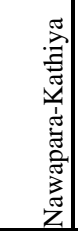 & 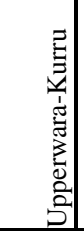 & 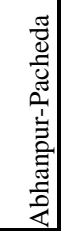 & 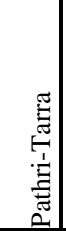 & 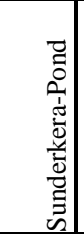 & $\begin{array}{l}z \\
\tilde{0} \\
2 \\
\text { 뜅 }\end{array}$ & 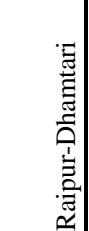 & $\begin{array}{l}5 \\
0 \\
\text { 文 } \\
0 \\
0\end{array}$ \\
\hline Car/Jeep/van/Three wheelers & 184 & 368 & 1746 & 50 & 221 & 368 & 23 & 18 & 355 & 2379 & 2286 & 7998 \\
\hline Motor Cycle/Scooters & 146 & 610 & 2563 & 154 & 256 & 610 & 47 & 44 & 658 & 2166 & 3086 & 10340 \\
\hline $\mathrm{LCV} / \mathrm{LGV}$ & 67 & 31 & 450 & 33 & 39 & 267 & 9 & 13 & 133 & 1093 & 599 & 2734 \\
\hline Bus & 11 & 6 & 186 & 7 & 2 & 43 & 3 & 0 & 43 & 59 & 357 & 717 \\
\hline Two Axel Truck & 39 & 61 & 590 & 64 & 62 & 157 & 66 & 74 & 180 & 2356 & 924 & 4573 \\
\hline Three axel Truck & 27 & 20 & 597 & 35 & 44 & 428 & 44 & 38 & 93 & 0 & 1448 & 2774 \\
\hline Multi Axel Truck & 32 & 106 & 681 & 18 & 30 & 255 & 34 & 30 & 68 & 1645 & 134 & 3033 \\
\hline Tractor & 86 & 760 & 1411 & 110 & 70 & 760 & 68 & 28 & 270 & 205 & 58 & 3826 \\
\hline Cycle/Cycle rickshaw & 212 & 845 & 3453 & 356 & 428 & 845 & 145 & 158 & 816 & 668 & 106 & 8032 \\
\hline Animal Drawn Vehicles & 80 & 318 & 324 & 17 & 3 & 318 & 7 & 15 & 24 & 8 & 0 & 1114 \\
\hline Total PCU & 1577 & 6068 & 18790 & 1186 & 1309 & 8716 & 871 & 784 & 3500 & 20746 & 13745 & 77288 \\
\hline Total & 884 & 3125 & 12001 & 844 & 1155 & 4051 & 446 & 418 & 2640 & 10579 & 8998 & 45141 \\
\hline
\end{tabular}

Source: PWD Office, and NH. Office, Raipur

In the Study area, the average daily traffic flow is 45141 from the selected roads. Traffic volume is relatively high on GE Road Raipur-Dhamtari Road and Jora-Vidhansava Road. The ADT flow is most uneven among the selected roads. It ranges from 418 on Pathri-Tarra Road to 12001 on JoraVidhansabha Road. Car, Motorcycle/Scooter and Cycles are most common vehicles in the study area. It accounts for $22.91 \%$ of the total traffic on selected roads. Whereas, buses are insufficient, amounting to only $1.59 \%$ of the total traffic. The value of PCU is also uneven in the study area. It ranges from 20746 on G.E. Road to 784 on Pathri-Tarra Road. The value of PCU is 18790 on JoraVidhansabha Road and 13745 on Dhamtari Road., which indicate that, increasing rate of traffic flow is relatively maximum in Jora-Vidhansabha Road.

\subsection{Registered Vehicles}

Table 5 shows the increasing rate of registered vehicles from 2007-08 to 2011-12. The number of Vehicles in the study area increased from 60949 in 2007-08 to 81136 in 2011-12 with a growth rate of $33.12 \%$. 
Table5. Number of Registered Vehicles (2007-08 to 2011-12)

\begin{tabular}{|l|c|c|r|r|r|r|}
\hline Types of Vehicles & $\mathbf{2 0 0 7 - 2 0 0 8}$ & $\mathbf{2 0 0 8 - 2 0 0 9}$ & $\mathbf{2 0 0 9 - 2 0 1 0}$ & $\mathbf{2 0 1 0 - 2 0 1 1}$ & $\mathbf{2 0 1 1 - 2 0 1 2}$ & $\begin{array}{l}\text { Growth } \\
\text { Rate in \% }\end{array}$ \\
\hline Mutltiaxled Vehicles & 867 & 798 & 746 & 651 & 596 & -31.26 \\
\hline $\begin{array}{l}\text { Medium, Heavey } \\
\text { Truck }\end{array}$ & 4077 & 2952 & 2093 & 1325 & 1941 & -52.39 \\
\hline $\begin{array}{l}\text { L. C. Vs ( Four } \\
\text { Wheelers) }\end{array}$ & 1387 & 1322 & 1477 & 1428 & 1678 & 20.98 \\
\hline $\begin{array}{l}\text { L. C. Vs ( Three } \\
\text { Wheelers) }\end{array}$ & 403 & 327 & 236 & 341 & 371 & -7.94 \\
\hline Buses & 149 & 115 & 156 & 98 & 44 & -70.47 \\
\hline Omni Buses & 561 & 485 & 428 & 400 & 670 & 19.43 \\
\hline Maxi Cab & 46 & 19 & 14 & 7 & 37 & -19.57 \\
\hline Motor Cab & 268 & 378 & 380 & 356 & 551 & 105.60 \\
\hline Auto Rickshaw & 633 & 536 & 623 & 1058 & 1175 & 85.62 \\
\hline Minidoor & 94 & 30 & 8 & 1 & 3 & -96.81 \\
\hline Moped & 4311 & 5415 & 5420 & 5046 & 4714 & 9.35 \\
\hline $\begin{array}{l}\text { Scooter Motor } \\
\text { Cycles }\end{array}$ & 39278 & 51875 & 49437 & 57993 & 56201 & 43.09 \\
\hline Cars & 4592 & 5154 & 6397 & 8037 & 8620 & 87.72 \\
\hline Jeeps & 3 & 19 & 16 & 7 & 256 \\
\hline Tractors & 2180 & 24 & 2588 & 2564 & 2801 & 28.49 \\
\hline Trailer & 1460 & 1 & 1463 & 1462 & 1170 & -19.86 \\
\hline Other Vehicles & 640 & 856 & 782 & 487 & 562 & -12.19 \\
\hline Total & $\mathbf{6 0 9 4 9}$ & $\mathbf{7 0 3 0 6}$ & $\mathbf{7 2 2 6 4}$ & $\mathbf{8 1 2 6 1}$ & $\mathbf{8 1 1 3 6}$ & $\mathbf{3 3 . 1 2}$ \\
\hline
\end{tabular}

Source: Road Transport Office, Raipur.

The number of registered Motor Cabs, Cars and Auto Rickshaws has significantly increased during the years (2007-08 to 2011-12). The increasing rates are $105.60 \%, 87.72 \%$ and $85.62 \%$ respectively. On the other hand, some vehicles recorded a decline in their growth rate during this period viz. Matador (-96.81\%), Buses (-70.47\%), Medium and Heavy Truck (-52.39\%), Jeeps (-33.33\%), Multi axel Vehicles (-31.26\%), Trailer (-19.86\%) and Maxi Cab (-19.57\%). The record of registered vehicles indicates that, personal vehicles have increased from 2007-08 to 2011-12.

\subsection{Proximity Analysis}

According to the first law of geography by Tobler (1970), everything is related to everything else but near things is more related than distant things. Thus, measurement of the distance between two objects is essential to evaluate their interdependency.

Proximity analysis is a useful technique to find out the relationship between a selected point (area) and its neighbours. This technique is also used to determine the distance between two locations and shortest route from one location to another. It ordains the relationship between selected geographic components by identifying the locations of the other elements within a particular distance (MicroImages, Inc., 2006). Proximity is defined as the ability to identify any feature that is near any other feature based on location, attribute value or a specific distance (Buckey). Proximity between two locations is divided into two categories i.e. features-based-proximity tools and raster-based distance tools. Where, the first one represents information with buffer features and the latter one show the distance of each cell from a set of features. Raster based distance tool also represents the shortest path across a surface. According to Michael De Mers (2005), buffering as "the process of creating areas of calculated distance from a point line or area object" (Trodd, 2005). It is the process of making one or more zones around the selected point, with a specified distance (Smith et. al., 2015). The result of buffer operation is always an area entity which is based on the location, shape and orientation of the input object (Trodd, 2005).

Although the buffers are used to delineate protected zones around the features, but in the case of Raipur Fringe, buffering process is used to show the distance from City centre (Raipur City) to each sample villages and road proximity of the villages. (Fig. 6\&7). Multi ring buffer tool is used to 
measure the distance from City Centre to the villages it classifies the areas around the City Centre into three categories as low, moderate and high distance zone. Low and high distance represents below 9 $\mathrm{km}$ and above $18 \mathrm{~km}$ distance respectively from the City Centre.

Fig. 5 shows that, only $13.08 \%$ of the total villages are located on the low distance buffer zone and $18.46 \%$ of the total villages are located on high distance buffer zone. Maximum villages of the fringe of Raipur City (more than 60\%) are concentrated on moderate buffer zone (9 to $18 \mathrm{~km}$. distance from city centre). Among the sample villages, the village Darba and Nagargaon are spread over 15 to 18 $\mathrm{km}$. buffer zone. The Village Dondekhurd, Siltara, Mana and Dhusera are concentrated on 12 to 15 $\mathrm{km}$. buffer zone. On the other hand, Sejbahar, Kanhera, Dhaneli, Tulsi and Hatband are located in 9 to $12 \mathrm{~km}$. buffer zone. There are only two villages viz. Jora and Kandul situated in 6 to $9 \mathrm{~km}$. buffer zone.

Figure 6 shows the village Siltara, Dhaneli, Dondekhurd, Mana, Jora and Sejbahar have major roads within $2 \mathrm{~km}$. buffer distance (Table 4.6). On the other hand there are no any major road link within 2 $\mathrm{km}$ buffer range in Dhusera, Kanhera, Darba, Nagargaon, Tulsi, Hatband and Kandul village. Major road is accessible within $8 \mathrm{~km}$. buffer zone from the centre point of Nagargaon village. In the study area, more than $60 \%$ of total villages (130) have no major road linkages within $2 \mathrm{~km}$. buffer distance.

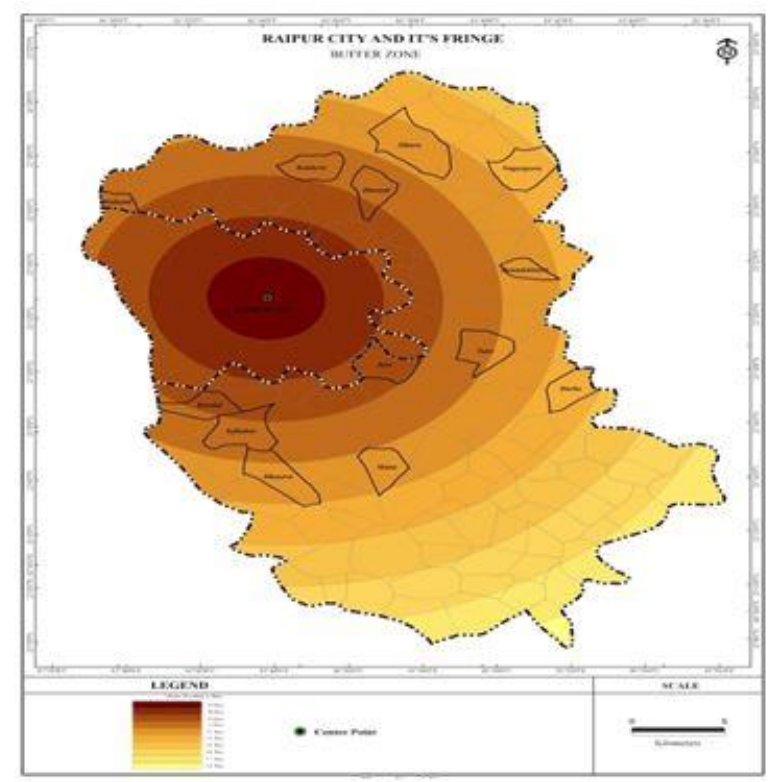

Fig5.

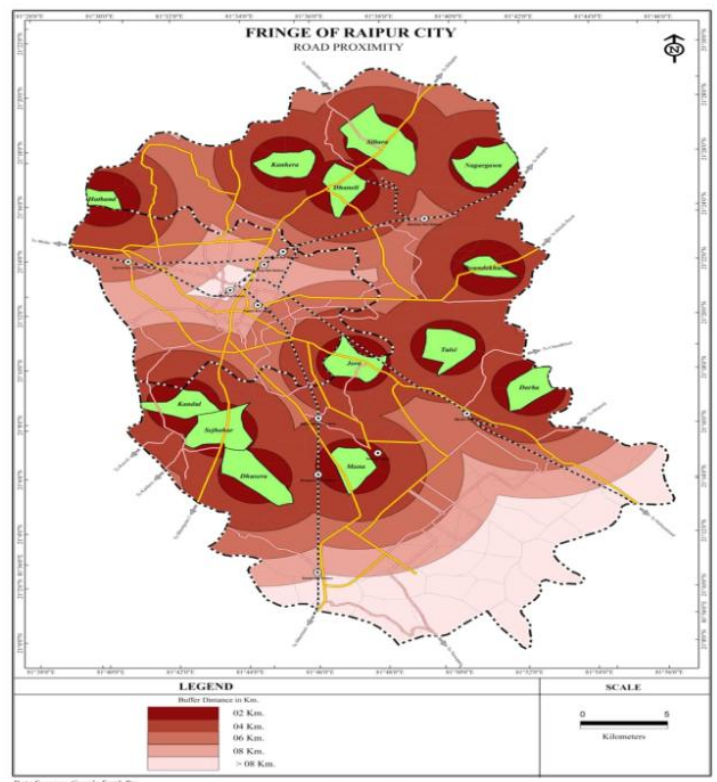

Fig6. 
Table6. Availability of Road Network in Sample Villages

\begin{tabular}{|c|c|c|c|c|}
\hline $\begin{array}{l}\text { Village } \\
\text { Type }\end{array}$ & $\begin{array}{l}\text { Village } \\
\text { Name }\end{array}$ & $\begin{array}{l}\text { Buffer Distance from } \\
\text { City Centre in Km. }\end{array}$ & $\begin{array}{l}\text { Major Roads } \\
\text { Linkage }\end{array}$ & $\begin{array}{l}\text { Minor Roads } \\
\text { Linkage }\end{array}$ \\
\hline \multirow{6}{*}{ 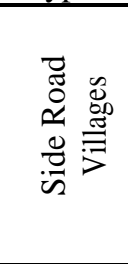 } & Doundekhurd & 15 & Within $2 \mathrm{Km}$. & Within $4 \mathrm{Km}$. \\
\hline & Sejbahar & 12 & Within $2 \mathrm{Km}$. & Within $2 \mathrm{Km}$. \\
\hline & Mana & 15 & Within $2 \mathrm{Km}$. & Within $2 \mathrm{Km}$. \\
\hline & Dhaneli & 12 & Within $2 \mathrm{Km}$. & Within $2 \mathrm{Km}$. \\
\hline & Jora & 9 & Within $2 \mathrm{Km}$. & Within $2 \mathrm{Km}$. \\
\hline & Siltara & 15 & Within $2 \mathrm{Km}$. & Within $2 \mathrm{Km}$. \\
\hline \multirow{7}{*}{$\begin{array}{l}\text { 心 } \\
\stackrel{0}{0} \\
\stackrel{0}{3} \\
\stackrel{0}{0} \\
\stackrel{0}{0}\end{array}$} & Dhusera & 15 & Within $4 \mathrm{Km}$. & Within $4 \mathrm{Km}$. \\
\hline & Kanhera & 12 & Within $4 \mathrm{Km}$. & Within $4 \mathrm{Km}$. \\
\hline & Darba & 18 & Within $4 \mathrm{Km}$. & Within $4 \mathrm{Km}$. \\
\hline & Nagargaon & 18 & Within $8 \mathrm{Km}$. & Within $8 \mathrm{Km}$. \\
\hline & Tulsi & 12 & Within $4 \mathrm{Km}$. & Within $2 \mathrm{Km}$. \\
\hline & Hatband & 12 & Within $4 \mathrm{Km}$. & Within $6 \mathrm{Km}$. \\
\hline & Kandul & 9 & Within $4 \mathrm{Km}$. & Within $2 \mathrm{Km}$. \\
\hline
\end{tabular}

Source: Personal Survey, 2011-12

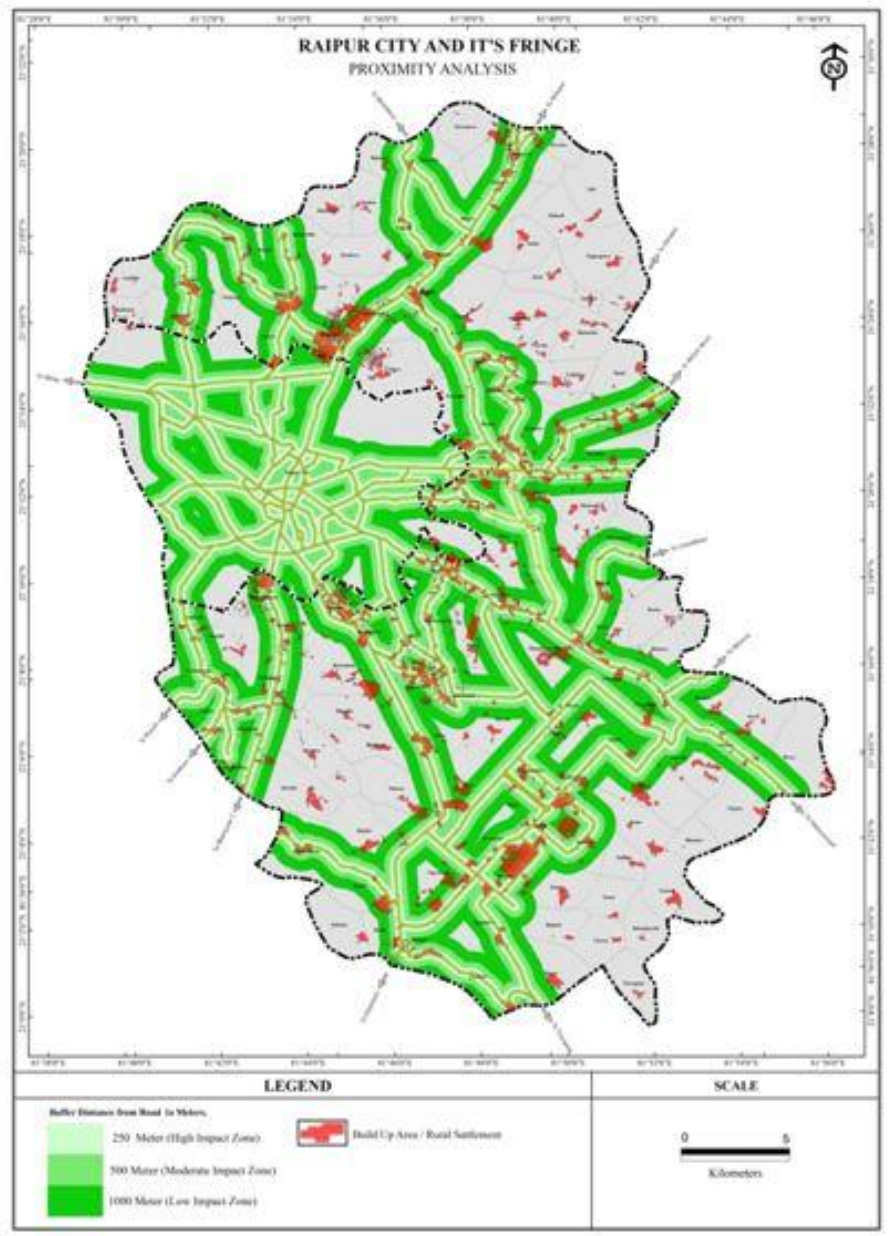

Fig7.

Figure7 shows the proximity of roads to the settlements. To evaluate the proximity of roads to the settlements, 250 meters, 500 meters and 1000 meters buffer zones are created from each road which indicate that, $41.54 \%$ of the total villages has no road proximity within 1000 meters buffer range. These buffer zones are also classified as high impact zone (250 meters distance from roads), moderate impact zone (500 meters distance from roads) and low impact zone (1000 meters distance from roads). High impact zone is characterized by high price of land, commercial activities, better sewage facility, better education and medical facility etc. In this zone, the average price of land is more than 12 to 15 lacks per acre. Maximum primary health centers $(60.45 \%)$ of the study area are located in 
high impact zone. Major percentages $(58.62 \%)$ of the high schools are located in this zone. On the other hand, price of land is 8 to 10 lacks in low impact zone. Only $14.69 \%$ of the total primary health centres and $18.25 \%$ of the total high schools of the study area are located in low impact zone.

\section{CONCLUSION}

The condition of road network is good and level of connectivity is moderate in the study area. Road density is so uneven, it ranges from below $2 \mathrm{~km}$./sq. km. to above $6 \mathrm{~km} . / \mathrm{sq}$. km. The density of roads is high in road side villages than remote villages. The connectivity level is also high in road side villages. In the remote villages, proximity of major roads is not available within the range of $2 \mathrm{kms}$. Road network infrastructure is also better in road side villages than in the remote villages. Almost all remote villages have no adequate metalled road connectivity in the fringe of Raipur City.

\section{REFERENCES}

Adrashannawar, S. M., "Geographic Analysis of the Quality of Roads in Mysore State, India", Abstracts of the papers of the 21st International Geographical Union Congress, New Delhi, 1968.

Awel, J., GIS Based Road Network Analysis in the Sub City of Arada, Msc. Thesis, Department of Earth Sciences, Addis Ababa University, 2007.

Balk, H .H., "Urbanization of wresters Economics", Ecological, Vol.18, 1957, pp. 104-118.

Behera, M., "Block Level Planning for Transport Development: A Case Study of a Backward Block in Orissa", in B.C. Vaidya (ed), in Readings in Transport Geography, Devika publication, Delhi, India, 1998, pp.251273.

Bhatta, B. P., Socioeconomic Transformations and Road Accessibility: Evidence from Northern Ethiopia, Msc. Dissertation, Department of Economics and Resource Management, Norwegian University of Life Sciences, 2004.

Bryant, C.R. et al., The City's Countryside: Land and Its Management in the Rural Urban Fringe, Addison - Westey Langman Ltd, 1982.

Doak, D. E, P. C. Marino and I. Kareiva, "Spatial Scale Mediates the Influence of Habitat Fragmentation on Dispersal Success: Implications for Conservation", Theoretical Population Biology, Vol.41, 1992, pp.315336.

Ford, A.C. et al., "Transport Accessibility Analysis Using GIS: Assessing Sustainable Transport in London", ISPRS Int. J. Geo-Inf4, 2015, 124-149; doi:10.3390/ijgi4010124.

Gairhe, B. R., Transportation Development and Challenges in Nepal: Case Study on Air Transportation Security, Thesis, Central University of Applied Sciences, 2013.

Gautam, P.S., Transport Geography of India: A Study of Chambal Division, M.P., Mittal Publication, New Delhi, India, 1992.

Hawbaker, T.J., et al., "Road Development, Housing Growth and Landscape Fragmentation in Northern Wisconsin: 1937-1999”, Ecological Applications, Vol.16 (3), 2006, pp. 1222-1237.

Ilayaraja, K., "Road network analysis in Neyveli Township, Cuddalore District by using Quantum GIS", Indian Journal of Computer Science and Engineering, Vol. 4, No.1, 2013, pp.56-61.

Jana, M.M., "Transport and Rural Development in Dakshmin Dinajpur District of West Bengal", in B.C. Vaidya (ed), In Readings in Transport Geography, Devika Publication, Delhi, India, 1998, pp.105-116.

Khan, Z.T. and T. R. Dehre, "Planning Strategy for Road Transport Network in Sheonath Basin Madhya Pradesh", in B.C. Vaidya (ed), In Readings in Transport Geography, Devika publication, Delhi, India, 1998, pp.203-218.

Lombard, P. and L. Coetzer, Estimating the Impact of Rural Road Investments on Socio Economic Development, African International Seminar on Sustainable Road Financing and Investment, 2007.

Manyazewal, A. L, et al., "Advanced Information System for Planning and Maintenance of Rural Road Using GIS", ISRS Proceeding Papers of Sort Interactive Session, ISPRS TC VIII International Symposium on, Operational Remote Sensing Applications: Opportunities, Progress and Challenges, 2014.

Michael, D. M., Vector Spatial Analysis (Buffers) - QGIS Documentation, 2005, https://docs.qgis.org/2.8/ en/docs/gentle_gis.../vector_spatial_analysis_buffers.html.

Nagne, A. D. et al., "Spatial Analysis of Transportation Network for Town Planning of Aurangabad City by Using Geographic Information System", International Journal of Scientific \& Engineering Research, Volume 4, Issue 7, 2013, pp.2588-2594.

Obafemi, A. A. et. al., "Road Network Assessment in Trans-Amadi, Por Harcourt in Nigeria Using GIS", International Journal for Traffic and Transport Engineering, Vol., 1(4), 2011, pp.257 - 264. 
Omoogun, C. B., The Centripetal Effects of Location on Rental Values of Residential Property in Metropolitan Lagos. Conference Proceedings on the Built Environment: Innovation Policy and Sustainable Development. Department of Architecture, Covenant University, Ota, Nigeria, 2006, pp.328 - 334.

Onuigbo I. C. and K.U.Orisakwe, "Applications of Geographic Information System and Remote Sensing in Road Monitoring in Minna and Environs, Nigeria"IOSR Journal of Environmental Science, Toxicology and Food Technology, Vol. 3, Iss. 6, 2013, pp. 01-05.

Patil, P. R., et al., "Transportation Network Analysis of Nanded Taluka by Using Geographic Information System", International Journal of Advanced Research in Computer Science and Software Engineering, Volume 5, Issue 4, 2015, pp.155- 158.

Raza, M. and Y. Aggarwal, Transport Geography of India, Concept Publishing Company, New Delhi, 1968.

Schumaker, N. H., "Using Landscape Indices to Predict Habitat Connectivity", Ecology, Vol.77, 1996, pp.1210-1225.

Sengupta, S., "Development of Road Monitoring and Management System Using G.I.S: A Profile," Indian Journal of Regional Science, Vol. 33, No. 1, 2001, pp. 121-126.

Sidhtharthan, S. and S. Durgadevagi, "Road Network Analysis of Pondicherry Union Territory Using GIS", International Journal of Technical Innovation in Modern Engineering \& Science, Vol. 2, Iss. 1, 2015, pp.32-41. Smith, D., et. al., Geospatial Analysis, 2015.

Sovik, B. R., "A GIS Method for Spatial Network Analysis Using Density, Angles, and Shape", American Journal of Geographic Information System, Vol. 3(1), 2014, pp. 23-37.

Taylor, P. D., L. Fahrig, K. Henein, and G. Merriam, "Connectivity is a Vital Element of Landscape Structure", Oikos, Vol. 68, 1993, pp.571-572.

Tobler W., "A computer movie simulating urban growth in the Detroit region", Economic Geography,46(Supplement),1970,234-240. https://en.wikipedia.org/wiki/Tobler\%27s first law of geography.

Trodd, N., Proximity Analysis: Buffering, 2005.

Walle, D., Impact Evaluation of Rural Road Projects, Draft Prepared for the World Bank, PREM Sector Evaluation Notes, 2007.

MSPI, Recent Trends in Sustainability and Management Strategy, 2014 https://books.google.co.in/ books?isbn=9385926551.

MicroImages, Inc., Lincoln, Nebraska, 2006.

AUTHOR'S BIOGRAPHY

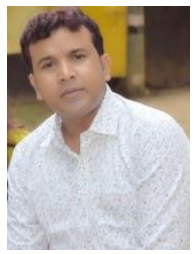

Dr. Shyama Prasanna Mukherjee, Completed Ph.D. form Pt. Ravishankar Shukla University, Raipur, CG. Now serving at Mahatma Gandhi College, Lalpur, WB.

Citation: Shyama Prasanna Mukherjee. "Road Connectivity and Proximity of Fringe of Raipur City, Chhattisgarh" International Journal of Research in Geography. vol 7, no.2, 2021, pp. 1-16 doi: http://dx.doi.org/10.20431/2454-8685.0702001.

Copyright: (c) 2021 Authors. This is an open-access article distributed under the terms of the Creative Commons Attribution License, which permits unrestricted use, distribution, and reproduction in any medium, provided the original author and source are credited. 